\title{
PSORIASIS AND PSORIATIC ARTHRITIS: CHARACTERISTICS AND RISK FACTORS AMONG ADULT PATIENTS IN EGYPT
}

Essam A. El-Moselhy, Ibrahim Saad Nada, Hamed O. Khalifa, Hassan M. Hassan* and Throwt M. Abd-Alrhman**

Departments of Community Medicine, Dermatology \& Venereology* and Orthopedics** Faculty of Medicine, Al-Azhar University

\begin{abstract}
Background: Psoriasis and psoriatic arthritis are common, chronic, immune mediated disease of the skin and joints. Interaction between genes and environment are important in disease causation.
\end{abstract}

Objectives: The aim of the present study was to determine the socioemographic and clinical characters of adult patients with psoriasis and those with psoriatic arthritis, to define psoriasis and psoriatic arthritis etiological risk factors, and to define the relationship between psoriasis severity and these items.

Subjects and methods: This study was conducted at Dermatology Clinic, Al-Hussein University Hospital. A case-control study design was chosen to perform this research. The study was conducted on 100 adult patients with psoriasis and an equal number of free adults as controls. Criteria for diagnosis of psoriasis and psoriatic arthritis were used. A comprehensive questionnaire was used to survey the studied groups. Body surface area of the affected patients was used as a marker of disease severity.

Results: The study showed that $44.0 \%$ of the cases had psoriasis age of onset; $22-45$ years. Stress was the most common etiological risk factor, $67.0 \%$. While, the most important risk factors were family history of psoriasis, recurrent pharyngitis, smoking $\geq 20$ cigarettes/ day and higher level of education, odds ratio $(\mathrm{OR})=7.58,5.94,2.78$ and 2.69, respectively. Also, $32.0 \%$ of the patients had psoriatic arthritis. Psoriatic arthritis comes after psoriasis and had mild severity in $65.6 \%$ and $68.7 \%$ of the cases, respectively. The most important etiological risk factors were severe psoriasis, smoking $\geq 20$ cigarettes/day and early onset of psoriasis, $\mathrm{OR}=9.64,3.06$ and 2.72 , respectively.

Conclusions and recommendations: The epidemiology of psoriasis is not well defined in Egypt. The heredity and environmental factors are the most important risk factors. Also, psoriatic arthritis is an important associated disease. The fact that it has no cure has important implications for how it should be viewed, prevented and treated. We recommend that more research should be carried out to understand the true epidemiological features of the disease in Egypt and its impacts on quality of life of the patients.

Key words: PSORIASIS, PSORIATIC ARTHRITIS, PATIENTS, EGYPT

\section{INTRODUCTION}

Psoriasis is a common, chronic, immune mediated disease of the skin and joints (Langley et al., 2005 and Griffiths et al., 2010). It affects about $1.0-3.0 \%$ of the general population (Koo, 1996; Grob \& Folchetti, 1999 and Stern et al., 2004). In the U.S., it affects over 7 million with approximately 260,000 new cases each year (Sander et al., 1993 and Weiss et al., 2002). While, incidence study indicates that 6 subjects/10000/year seeking care for psoriasis for the first time (Bell et al., 1991). Psoriasis is characterized by thick, scaling, red plaques that can be localized 
or widespread. Morphological variants are common (Griffiths et al., 2010). The disease can be disfiguring and associated with itching and arthritis (Lebwohl \& Ali, 2001a and Lebwohl \& Ali, 2001b).

It appears that psoriasis has a bimodal distribution of age of onset; the larger, early peak between 16 and 22 years and the later one at 57-60 years (Henseler and Christophers, 1985; Smith et al., 1993 and Ferrandiz et al., 2002). Also, males and females are equally affected (Griffiths et al., 2010).

Hereditary plays an important role in the genetics of psoriasis (Griffiths et al., 2010). Support comes from analysis of various family pedigrees in which psoriasis appears throughout multiple generations (Elder et al., 1994). Also, twins' studies are the most robust evidence that support a genetic basis to psoriasis (Farber and Nall, 1974; Brandrup et al., 1982; Duffy et al., 1993 and Griffiths et al., 2010).

Evidence indicates that interaction between genes and the environment are important in disease causation (Bhalerao and Bowcock, 1998). Many environmental factors have been linked to psoriasis, and have been implicated in, such as disease process initiation or exacerbation. However, conclusive evidence is so far lacking (Griffiths et al., 2010). Environmental risk factors include; trauma (Eyre and Krueger, 1984), infections (Tervaert \& Esseveld, 1970 and Telfer et al., 1992), drugs (Griffiths et al., 2010), sunlight (Ros and Eklund, 1987), the 3-month postpartum period (Dunna and Finlay, 1989), stress (Griffiths et al., 2010), seasonal variation (Bell et al., 1991), and smoking and alcohol (Griffiths et al., 2010).

There is no cure for psoriasis; the aim of treatment is to control the disease (Krueger et al., 2001). Further, treatment of psoriasis adds substantial costs to the health care system (Javitz et al., 2002) and may also be associated with many problems (Stern, 2003). Psoriasis in elderly patients represents a more challenge for many reasons related to both of the patient and disease. Older and married patients reported less affection than younger and those living alone (Yosipovitch \& Tang, 2002 and Zachariae et al., 2002b).

Psoriatic arthritis is an inflammatory arthritis, immune mediated disease of the joints, associated with psoriasis (Moll and Wright, 1973a and Langley et al., 2005). It presents more burdens for psoriasis patients. Estimates of the prevalence of psoriatic arthritis in patients with skin psoriasis vary from $5.0 \%$ to $42.0 \%$ (Mease and Goffe, 2005). Accurate studies place the prevalence towards the higher end of the range (Gladman, 2002). The prevalence of psoriatic arthritis in patients with skin psoriasis is $23.0 \%$ in the U.S. (Griffiths et al., 2010) and $30.0 \%$ in Scandinavia (Zachariae et al., 2002b). Although, there are no large studies taking psoriatic arthritis into consideration when studying psoriasis (Zachariae et al., 2002b and Griffiths et al., 2010). Recent community-based epidemiologic studies have suggested a prevalence rate of psoriatic arthritis of $1 / 1000$, male to female ratio is $1: 1$ and peak incidence between ages 45-54 years (Petros and Joseph, 2006).

Psoriasis can have a tremendous effect on patients' lives; physical and psychosocial (Langley et al., 2005 and Choi \& Koo, 2008). Also, psoriasis patients are more likely to be anxious and depressed (Devrimci-Ozguven et al., 2000 and Stein et al., 2005). Further, stress has an important role in onset and 
exacerbation of psoriasis (Griffiths et al., 2010).

The aim of this study is to determine the sociodemographic and clinical characters of adult patients with psoriasis and psoriatic arthritis, to define the epidemiological risk factors of both of them, and to determine the relationship between psoriasis severity and these items.

\section{SUBJECTS AND METHODS}

I- Research Setting: This study was conducted at Dermatology Clinic, AlHussein Hospital, Al-Azhar University.

II- Research Desiegn: A case-control, clinic-based study design was chosen to perform this study.

III- Research Sample: According to sample size equation the studied group was calculated to be 45 patients with current clinical diagnosis of psoriasis. To guard against bias and cases dropout we doubled the sample size to be 100 adult cases. An equal number of free, normal adults were chosen randomly as controls. Both psoriasis patients and controls were matched in age; their ages were 20-64 year.

IV- Ethical Consederations: The purpose and procedures to be performed were explained to the patients and controls. Accordingly, a verbal consent to participate in the study was taken from both of the patients and controls.

V- Research Tools: A comprehensive questionnaire was used to survey the studied groups. The questionnaire included sociodemographic and clinical characteristics, and etiological risk factors of the disease.

VI- Research Methods: Extent of psoriasis was determined by the body surface area (BSA) of the affected patient, which could be covered by the palm of the patient's hand. This method has been used as a marker of psoriasis severity. BSA was classified as $1.0-2.0 \% \mathrm{BSA}=$ no or very little psoriasis (mild), only a few patches that could be covered by 1-2 palms; 3.0$10.0 \% \mathrm{BSA}=$ scattered patches that could be covered by 3-10 palms (moderate), and $>10.0 \% \mathrm{BSA}=$ extensive disease covering large areas of the body that could be more than 10 palms (severe) (Feldman et al., 1996 and Gelfand et al., 2004).

Psoriatic arthritis was diagnosed by presence of joint symptoms as pain, swelling and restriction of joint mobility; absence of rheumatoid nodules, negative serological test for rheumatoid factor and radiological manifestations, which also indicate degree of arthritis severity (Moll and Wright, 1973a). Also diagnosis of psoriatic arthritis was based on:

1- The distinct patterns of it as i) Oligoarticular especially DIP joint affection, associated with ductylitis (sausage appearance), ii) Assymmetric involvement of DIP joints of hands and feet with nail changes, iii) Arthritis (disabling form) due to osteolysis, iv) Symmetric polyarthritis as RA but-ve RF, v) Psoriatic spondyloarthropathy, vi) Enthesopathy, vii) Extra-articular manifestations as conjunctivitis, uveitis and aortic insufficiency, and viii) Saphoo syndrome.

2- Physical examination shows cardinal signs of i) Inflammation of peripheral joints, spine and SI joints, ii) Skin psoriasis, and iii) Nail changes.

3- No definite laboratory tests.

4- Radiographic erosions in fingers of hands and feet (with pencil-incup appearance of DIP joints), spine and SI joints (Petros and Joseph, 2006).

VII- Statistical Analysis: Chi-Square $\left(\chi^{2}\right)$, Fisher exact (FE) or odds ratio (OR) were used as tests of significance. The significance level for $\chi^{2}$ and FE was accepted if the P-value $<0.05$. The significance level for OR was the 
confidence interval (CI) or exact confidence limits (ECL).

\section{RESULTS}

As regard distribution of the studied group of adult patients with psoriasis according to their clinical characteristics (table 1), 37.0\%, 44.0\% and $19.0 \%$ of the patients their disease age of onset was <25, 25-45 and >45 years, respectively. The average age of onset was 31 years. Also, $52.0 \%$ of the cases were females. Further, $68.0 \%$ and $32.0 \%$ of the patients had disease duration $<15$ and $\geq 15$ years, respectively. Also, $72.0 \%, 16.0 \%$ and $12.0 \%$ of the patients had stationary, regression and progressive course, respectively. As respect severity, 36.0\%, $38.0 \%$ and $26.0 \%$ of the cases had mild, moderate and severe forms of disease. Also, $56.0 \%$ of the patients had psychological disturbances. In details, $27.0 \%, 17.0 \%$ and $12.0 \%$ of them had pathological worry, anxiety and depression, respectively. Further, $32.0 \%$ of the cases had associated psoriatic arthritis. Also, $71.0 \%$ of the patients' disease was more in winter. Further, $82.0 \%$ of the patients suspected their disease etiological risk factors; $81.7 \%$ of them suspected stress, $46.9 \%$ of the married female patients suspected that disease worsens in the 3-month post-partum, and in $9.4 \%$ of them the disease worsens during pregnancy. Also, $17.1 \%$ of the patients the disease was found in uninvolved skin due to trauma, sun light was recognized as a cause of psoriasis in $2.4 \%$ of the patients, and medical therapy was accused in $2.4 \%$. Lastly, psoriasis suspected to improve in $43.8 \%$ and $12.5 \%$ of the patients during pregnancy and post partum period, respectively.

Regarding distribution of psoriasis patients and controls according to their sociodemographic risk factors (table 2), single was significant risk factor $(\mathrm{OR}=$
2.93, 95\% CI: 1.50-5.74). Also, secondary and university education was significant risk factor for psoriasis $(\mathrm{OR}=2.69,95 \%$ CI: 1.13-6.49). While, semi-skilled \& skilled, and professional jobs were insignificant risk factors $(\mathrm{OR}=1.62,95 \%$ CI: $0.87-3.04$ and $\mathrm{OR}=1.38,95 \%$ CI: $0.51-$ 3.77; respectively). Collectively, middle and high social classes were insignificant risk factors $(\mathrm{OR}=1.30,95 \% \mathrm{CI}: 0.70-2.43$ and $\quad \mathrm{OR}=2.07, \quad 95 \% \quad \mathrm{CI}: \quad 0.82-5.35$; respectively).

As respect distribution of psoriasis patients and controls according to presence of some etiological risk factors (table 3), male sex was insignificant risk factor of psoriasis $(\mathrm{OR}=1.08,95 \% \mathrm{CI}: 0.60-1.96)$. History of recurrent pharyngitis was significant risk factor $(\mathrm{OR}=5.94,95 \% \mathrm{CI}$ : 2.53-14.30). While, smoking was insignificant risk factor $(\mathrm{OR}=1.64,95 \%$ CI: 0.90-3.01). The risk became significant with increasing number of cigarettes/day to $\geq 20$ cigarettes/day ( $O R=$ 2.78, 95\% CI: 1.41-5.50). Further, stress or worry was significant risk factor of psoriasis (OR=1.83, 95\% CI: 1.01-3.34). While, job exposing the psoriasis patients to sunlight was insignificant risk factor ( $\mathrm{OR}=1.78$, 95\% CI: 0.79-4.05). Further, some medications and psoriasis at site of trauma were risk factors for psoriasis, with undefined risks.

Regarding distribution of psoriasis patients and controls according to family history risk factors (table 4), family history of psoriasis was significant risk factor (OR=7.58, 95\% ECL: 2.10-41.07). In details, family history of $1^{\text {st }}$ and $2^{\text {nd }}$ degree or more relatives with psoriasis were significant risk factors $(\mathrm{OR}=7.32$, 95\% ECL: $1.58-68.08$ and OR=undefined; respectively). Also, in these patients with a family history of $1^{\text {st }}$ degree relatives with psoriasis; the two parents and one sibling with psoriasis were undefined risk factors. 
In more details, the risk to have psoriasis in patients with one parent with psoriasis was insignificant.

As regard distribution of psoriasis patients' severity status by risk factors (table 5), $69.2 \%$ of the patients with severe psoriasis were singles $(\mathrm{P}=0.002)$. Further, $34.6 \%$ of the patients with severe psoriasis had secondary or university education $(\mathrm{P}=0.2)$. Also, the disease had late age of onset ( $>45$ years) in $30.5 \%$ of the patients with mild disease $(\mathrm{P}=0.03)$. Also, $69.2 \%$ of the patients with severe psoriasis smoked $\geq 20$ cigarettes/day $(\mathrm{P}=$ 0.001 ). Moreover, $88.5 \%$ of the patients with severe psoriasis had stress or worry $(\mathrm{P}=0.0003)$. Further, $100.0 \%$ of the patients with severe psoriasis had history of recurrent pharyngitis $(\mathrm{P}=0.01)$. Also, $34.6 \%$ of the patients with severe psoriasis had family history of psoriasis $(\mathrm{P}=0.05)$. Lastly, $57.7 \%$ of the patients with severe psoriasis had psoriatic arthritis $(\mathrm{P}=0.002)$.

As regard distribution of the studied group of adult patients with psoriatic arthritis according to their clinical characteristics (table 6), 65.6\%, $18.8 \%$ and $15.6 \%$ of psoriatic arthritis patients had disease onset after, before and simultaneously with psoriasis, respectively. Also, the average age of onset was 43 years. Regarding gender, $53.1 \%$ of the cases were females. At the same time, $56.2 \%$ of the patients had duration $<10$ years. Further, $84.3 \%$ and $9.4 \%$ of the cases had stationary and progressive course, respectively. Also, $68.7 \%, 25.0 \%$ and $6.3 \%$ of the cases had mild, moderate and severe diseases, respectively. Further, $71.9 \%$ of the patients had more disease in winter. Lastly, trauma as a suspected etiological cause was found in $9.4 \%$ of the patients.

Regarding distribution of psoriatic arthritis patients and controls according to some etiological risk factors (table 7), the male gender was insignificant risk factor of psoriatic arthritis $(\mathrm{OR}=1.04,95 \% \mathrm{CI}$ : 0.43-2.47). Also, history of recurrent pharyngitis was insignificant risk factor of psoriatic arthritis $(\mathrm{OR}=2.1,95 \%$ CI: 0.77 5.94). Further, family history of psoriatic arthritis was insignificant risk factor (OR=6.6, 95\% ECL: 0.33-393.18). While, smoking was significant risk factor of psoriatic arthritis (OR=4.98, 95\% ECL: 1.69-17.73). Further, the risk increase significantly with increasing number of smoked cigarettes/day; $\geq 20 \quad(\mathrm{OR}=5.85$, 95\% CI: 2.29-15.16). Lastly, psoriatic arthritis at site of trauma of patients and controls was insignificant risk factor of psoriatic arthritis $(\mathrm{OR}=10.24$, 95\% ECL: 0.77-542.86).

Regarding distribution of psoriasis patients according to presence of psoriatic arthritis by some clinical risk factors (table 8), early age of onset ( $<25$ years) was significant risk factor in patients with psoriasis to develop psoriatic arthritis $(\mathrm{OR}=2.72,95 \% \quad \mathrm{CI}:$ 1.05-7.12). Also, smoking $\geq 20 \quad$ cigarettes/day was insignificant risk factor in patients with psoriasis to develop psoriatic arthritis (OR=3.06, 95\% CI: 1.18-8.02). Further, family history of psoriatic arthritis was insignificant risk factor in patients with psoriasis to develop psoriatic arthritis (OR=4.47, 95\% ECL: 0.22-267.35). Lastly, severe psoriasis was significant risk factor in patients with psoriasis to develop psoriatic arthritis $(\mathrm{OR}=9.64,95 \%$ CI: 3.15-30.55).

As regard distribution of psoriasis patients according to presence of psoriatic arthritis by some clinic-demographic characteristics (table 9), 59.4\% and 33.8\% of the patients with- and without psoriatic arthritis were singles, respectively with a statistically significant difference $(\mathrm{P}=$ 0.02 ). Also, $18.8 \%$ and $25.0 \%$ of patients with- and without psoriatic arthritis, 
respectively had secondary or university education with statistically insignificant difference $(\mathrm{P}=0.6)$. Further, $78.1 \%$ and $97.1 \%$ of the patients with- and without psoriatic arthritis, respectively had history of recurrent pharyngitis with a statistically significant difference $(\mathrm{P}=0.004)$. Further, $90.6 \%$ and $39.7 \%$ of the patients with- and without psoriatic arthritis, respectively had stress/worry with a statistically significant difference $(\mathrm{P}=0.000)$. Lastly, $9.4 \%$ and $0.0 \%$ of the patients with- and without psoriatic arthritis, respectively had arthritis at site of trauma with a statistically significant difference $(\mathrm{P}=0.03)$.

\section{DISCUSSION}

Psoriasis is a common, chronic disease of the skin and joints (Langley et al., 2005 and Griffiths et al., 2010). The disease affects up to $3.0 \%$ of the population (Grob \& Folchetti, 1999 and Stern et al., 2004). In this study we try to explore risk factors and epidemiology of this disease in Egypt.

In the present study we cleared that $37.0 \%, 44.0 \%$ and $19.0 \%$ of the patients their disease age of onset was $<25,25-45$ and $\geq 46$ years. It has been reported that $35.0 \%$ of cases have disease onset before age 20 years and $58.0 \%$ before age 30 (Farber and Nall, 1985). While, it was found that $75.0 \%$ of cases have disease onset before the age of 40 and 46 years in tow studies (Henseler \& Christophers, 1985 and Nevitt \& Hutchinson, 1996). Also, our results were in consistent with Smith et al. (1993) who showed that psoriasis has a bimodal distribution of age of onset; the larger, early peak at 16- 22 years and the later one at 57-60 years. In the present study we cleared that we cleared that the average age of onset was 31 years. This figure was found between 28 and 36 years, the figures reported by Farber \& Nall (1974) and
Yui Yip (1984), respectively. Also, we noticed that $48.0 \%$ and $52.0 \%$ of cases were males and females, respectively. Griffiths et al. (2010) stated that males and females are equally affected, but females may have a younger age of onset, 16 years than males, 22 years (Henseler and Christophers, 1985). Also, we reported that $68.0 \%$ and $32.0 \%$ of the patients had duration of the disease $<15$ and $\geq 15$ years, respectively. This is expected as psoriasis is a chronic, recurrent disease (Langley et al., 2005 and Griffiths et al., 2010). In the present study we observed that $72.0 \%$ of the patients had stationary course. Again, this is expected as psoriasis is a chronic, recurrent disease with no cure (Krueger et al., 2001). On the other hand, $39.0 \%$ of patients reported complete remission of disease for between one and 54 years (Farber and Nall, 1974). As regard severity, only $26.0 \%$ of cases were severe. This was in accordance with McKenna et al. (2005) who reported $30.6 \%$. In the present study we showed that $56.0 \%$ of the patients had psychological disturbances. In details, $27.0 \%, 17.0 \%$ and $12.0 \%$ of them had pathological worry, anxiety and depression, respectively. Our results were more than Savin (1970) and Fortune et al. (1997), they reported that pathological worry and anxiety occur in at least a third of patients with psoriasis and that psychological interpersonal difficulties impinge on all aspects of the patient's daily life (Kirby et al., 2000\&2001). Also, we cleared that $32.0 \%$ of the cases had associated psoriatic arthritis. Psoriasis is an immune mediated disease of the skin and joints (Langley et al., 2005 and Griffiths et al., 2010). Our figure was higher than Griffiths et al. (2010), 23.0\% and close to Zachariae et al. (2002a), $30.0 \%$. Regarding seasonal variation, $71.0 \%$ of the patients had disease more in 
winter. This was consistent with Bell et al. (1991) who reported that $68.0 \%$ of cases first diagnosed in winter. In the present study we showed that stress as a suspected risk factor was found in $67.0 \%$ of the patients. This result was in accordance with Fortune et al. (1998); they reported that more than $60.0 \%$ of their psoriasis patients believed that stress was a principle factor in causation of their disease. Also, stress reactivity was correlated with worse disease and more exacerbations (Gupta et al., 1989). Further, psoriasis patients with pathological worry were less likely to clear with photo-chemotherapy than those with low worry (Fortune et al., 2003). But how psychological distress exacerbates or triggers psoriasis is poorly understood (Farberb \& Nall, 1974 and Langley et al., 2005). Also, we showed that $46.9 .0 \%$ of the married female patients stated that the disease worsens at the 3-month postpartum. While, in $9.4 \%$ of them the disease worsen during pregnancy. Psoriasis deteriorated in $54.0 \%$ of the patients in the 3-month postpartum period and it worsened in $14.0 \%$ of pregnancies (Dunna and Finlay, 1989). In the present study we cleared that $14.0 \%$ of the patients the disease was caused in uninvolved skin due to trauma. Psoriasis at the site of injury is well known, Koebner phenomenon. This figure is smaller than $38.0 \%$ reported by Farberb and Nall (1974). This may be due to small number of our cases compared to their 5600 cases. A wide range of injurious local stimuli, such as physical, chemical, electrical, surgical and inflammatory insults has been recognized to elicit psoriasis (Eyre and Krueger, 1984). Also, we reported that sun light was recognized as a cause of psoriasis in $2.0 \%$ of our patients. Ros and Eklund (1987) showed that in $5.5 \%$ of patients disease may be provoked by strong sunlight and cause exacerbation in exposed skin. Further, we observed that medical therapy was accused in $2.0 \%$ of our patients. Griffiths et al. (2010) stated that many drugs are responsible for the onset or exacerbation of disease. The most important among these drugs are lithium and anti-malarial drugs. Lastly, psoriasis improved in $43.8 \%$ and $12.5 \%$ of our patients during pregnancy and post partum period, respectively. Dunna and Finlay (1989) cleared that psoriasis improved in about $40.0 \%$ of pregnancies and in $11.0 \%$ of the 3-month postpartum period. So, it is more likely that psoriasis improve during pregnancy than worsen, while in postpartum period it is more likely to worsen (Boyd et al., 1996).

In this study we observed that single state was significant risk factor of psoriasis $(\mathrm{OR}=2.93,95 \% \mathrm{CI}: 1.50-5.74)$. Yosipovitch \& Tang (2002) and Zachariae et al. (2002b) stated that patients living alone reported more affection than married patients. At the same time, our result showed an interesting observation that higher social class in psoriasis patients was about double that of controls $(17.0 \%$ vs. $9.0 \%)$ and present a 2 -fold insignificant risk to have psoriasis. Social class determines a lot of lifestyle markers that could be risk factors for psoriasis; these factors include smoking, stress, jobs exposing subject to sunlight...etc.

We cleared males and females were equally affected with psoriasis; however females may have a younger age of onset (Griffiths et al., 2010). Also, we showed that history of recurrent pharyngitis was significant risk factor of psoriasis. This result was consistent with Tervaert \& Esseveld (1970) and Telfer et al. (1992); they stated that streptococcal infection, especially of the throat, may be important in psoriasis. Also, our high figure of pharyngitis may be due to 
chronic streptococcal pharyngitis is common in Egypt. Further, we cleared that smoking was insignificant risk factor. It has long been stated that cigarettes has a detrimental effect on psoriasis (Griffiths et al., 2010), although, recent epidemiological studies not observed conclusive support for that association (Higgins, 2000). Also, we reported that patients who smoked $\geq 20$ cigarettes/day had about 3 times risk to have psoriasis. Females who smoked $>15$ cigarettes/day had 3.9 times risk to have psoriasis, while males had 1.4 (Naldi et al., 1999). Moreover, our result as regard stress was in accordance to Gupta et al. (1989), who stated that stress reactivity was correlated with more exacerbations of disease. Psoriasis causes high level of emotional distress (Rapp and Feldman, 2004). These emotional distresses include anxiety, depression and anger (Choi and Koo, 2008). Also, Devrimci-Ozguven et al. (2000) cleared that psoriasis patients are more likely to be depressed. Further, House and Stark (2002) showed that anxiety is more common in patients with chronic medical illnesses as psoriasis. Moreover, our results were consistent with Savin (1970) and Fortune et al. (1997), they identified that pathological worry and anxiety occur in at least a third of patients with psoriasis. The two main contributors to stress in patients with psoriasis are engaging in avoidance behavior and the belief that they are being evaluated on the basis of their skin disease. This constraining, avoidance behavior may lead to low grade persistent stress (Kirby et al., 2000\& 2001). So, stress management program was significantly shortened the time to clearance with standard therapies (Fortune et al., 2002). Also, our finding that jobs exposing our cases to sunlight were risk factor was inconsistent with Ros and Eklund (1987), they showed that strong sunlight may provoke disease and cause exacerbation in exposed skin in $5.5 \%$ of cases. Further, we noticed that psoriasis patients used to accused medical treatments as risk factor for psoriasis was in accordance with Griffiths et al. (2010). Also, psoriasis at site of trauma might be considered risk factor for psoriasis was in consistent with Farberb \& Nall (1974) and Eyre \& Krueger (1984).

In the present study, family history of psoriasis was significant risk factor. There is overwhelming evidence that psoriasis has an important genetic component (Griffiths et al., 2010). In details, $13.0 \%, 6.0 \%$ and $2.0 \%, 0.0 \%$ of patients and controls respectively had family history of $1^{\text {st }}$ and $2^{\text {nd }}$ degree or more relatives with psoriasis. Hellgren (1967) reported that prevalence of psoriasis was $7.8 \%$ among first degree relatives compared with $3.1 \%$ in controls and about $2.0 \%$ in general population. Also, in these patients with a family history of $1^{\text {st }}$ degree relatives with psoriasis there were $9.0 \%, 3.0 \%$ and $1.0 \%$ of the patients had one parent, two parents and one sibling with psoriasis. In more details, $4.0 \%$ and $1.0 \%$ of the patients with one parent with psoriasis had a paternal and maternal history of psoriasis respectively. The risk for a child to develop psoriasis was $14.0 \%$ if one parent was affected, $41.0 \%$ if both parents affected and $6.0 \%$ if one sibling affected, compared to $2.0 \%$ when no parent or sibling was affected (Andressen and Henseler, 1982). Moreover, Farber and Nall (1974) showed concordance for psoriasis in $73.0 \%$ of monozygotic twins compared to $20.0 \%$ for dizygotic twins. Also, Brandrup et al. (1982) found concordance for psoriasis in $64.0 \%$ of monozygotic twins compared to $15.0 \%$ for dizygotic twins, corresponding to an estimated heritability of $91.0 \%$. While, 
Duffy et al. (1993) noticed lower concordance; $35.0 \%$ in monozygotic twins compared to $12.0 \%$ in dizygotic twins. Of interesting that concordance rates do not reach $100.0 \%$, even when older twins are examined, indicating that the environment plays a key part in disease expression. So, it is likely that changes in multiple genes, interacting both with each other and the environment, are required for disease expression (Barker, 2007 and Griffiths et al., 2010).

We reported $69.2 \%$ of the patients with severe psoriasis were single. Patients with severe psoriasis might have no chance to be married due to their disease. Yosipovitch \& Tang (2002) and Zachariae et al. (2002b) cleared that patients living alone have more affected QOL than married patients. Also, early age of onset was observed in $53.8 \%$ of the patients with severe psoriasis. This result concur with Farber \& Nall (1974); Henseler \& Christophers (1985); Gudjonsson et al. (2002) and Stuart et al. (2002), they cleared that patients with early disease onset appear to have more severe psoriasis. Further, the disease had late age of onset in $30.5 \%$ of the patients with mild disease. This result concurs with Henseler \& Christophers (1985) and Gudjonsson et al. (2002); they noticed that the patients with late disease onset their psoriasis appears to be mild. Also, we showed that $69.2 \%$ of the patients with severe psoriasis smoked $\geq 20$ cigarettes/ day. Smoking $>15$ cigarettes/day increased the risk to have psoriasis by 1.4 and 3.9 times in males and females, respectively (Naldi et al., 1999), so smoking > 20 cigarettes/day might be increased the risk to have, also, severe psoriasis. Moreover, $88.5 \%$ of our patients with severe psoriasis had stress and/or worry. Patients with severe psoriasis experienced episodes of higher rates of psychological morbidity
(Gupta et al., 1998). On the other hand, Kirby et al. (2000\&2001) found no significant relation between both the physical severity and psychological disability. This observation implies that "severity" of psoriasis is a composite of physical and psychological factors, a disparity further highlighted by the Psoriasis Disability Index (Finlay and Kelly, 1987). Recently, Bos and DeCorte (2008) showed that some new psoriasis therapies might relief symptoms of depression. Further, $100.0 \%$ of our patients with severe psoriasis had history of recurrent pharyngitis. Tervaert \& Esseveld (1970 and Telfer et al. (1992) cleared that streptococcal pharyngtis may be important in psoriasis. Moreover, association between severe psoriasis and HIV infection was noted (Reveille et al., 1990). Lastly, $57.7 \%$ of our patients with severe psoriasis had psoriatic arthritis. This was in consistent with Leonard et al. (1978); they stated that it appears that psoriatic arthritis is more common in patients with severe form of the disease.

In the present study we observed that $65.6 \%, 18.8 \%$ and $15.6 \%$ of the psoriatic arthritis patients had disease onset after, before and simultaneously with psoriasis, respectively. All these are expected as psoriasis is a chronic, immune mediated disease of the skin and joints (Langley et al., 2005 and Griffiths et al., 2010). These results were in consistent with Scarpa et al. (1984); they showed that psoriasis found to proceed, after and with arthritis in $65.0 \%, 19.0 \%$ and $16.0 \%$ of their psoriasis patients, respectively. Also, these results were in consistent with Biodi-Oriente et al. (1989), as they reported $68.0 \%, 21.0 \%$ and $11.0 \%$. Also, we showed that the average age of disease onset was 43 years. In general the peak age of onset for psoriatic arthritis is in $4^{\text {th }}$ decade. So, our figure was in consistent 
with Biodi-Oriente et al. (1989) figure. Further, we noticed that $46.9 \%$ and $53.1 \%$ of our cases were males and females, respectively. Griffiths et al. (2010) stated that males and females appear equally affected. Also, $56.2 \%$ and $43.8 \%$ of the patients had duration of the disease $<10$ and $\geq 10$ years, respectively. This is expected as psoriatic arthritis is a chronic inflammatory disease (Moll \& Wright, 1973a and Griffiths et al., 2010). Further, we showed that $84.3 \%$ and $9.4 \%$ of the cases had stationary and progressive course, respectively. Also, 68.7\%, 25.0\% and $6.3 \%$ of the cases were mild, moderate and severe, respectively. These results were in accordance with Roberts et al. (1976) and in contrast with Gladman et al. (1987). Thus there is no conclusive data regarding prognosis. In the present study we reported that $71.9 \%$ of the patients had more disease in winter. This was concurring with Bell et al. (1991). Lastly, trauma as a suspected etiological factor was found in $9.4 \%$ of the patients.

Punzi et al. (1998) stated that trauma as a precipitating factor for psoriatic arthritis was observed and might be appear important.

We cleared that males and females were equally affected by psoriatic arthritis; $46.9 \%$ and $53.1 \%$, respectively. This result was in accordance with Griffiths et al. (2010); they stated males and females are equally affected. Also, environment may have a good component in pathogenesis of the disease; studies indicate that the disease aggregates in certain families (Moll and Wright, 1973b). Further, we reported that history of recurrent pharyngitis was insignificant risk factor $(\mathrm{OR}=2.10, \quad 95 \% \quad \mathrm{CI}: \quad 0.77-5.94)$. So, increase positive streptococcal immunoreactivity in these patients' sera was noticed (Vasey et al., 1982). The high figures of chronic pharyngitis in the patients and controls may be due to the disease is chronic in Egypt. At the same time, family history of psoriatic arthritis was insignificant risk factor of psoriatic arthritis (OR=6.60, 95\% ECL: 0.33 393.18). Hellgren (1969) cleared that psoriatic arthritis had familial clustering, although Griffiths et al. (2010) stated that it less is common than for psoriasis. Also, we observed that smoking was significant risk factor of psoriatic arthritis $(\mathrm{OR}=4.98$, 95\% ECL: 1.69-17.73). It has long been stated that cigarettes has detrimental effects (Griffiths et al., 2010). Lastly, psoriatic arthritis at site of trauma was considering insignificant risk factor $(\mathrm{OR}=$ 10.24, 95\% ECL: 0.77-542.86). This result was concurring with Punzi et al. (1998) and Griffiths et al. (2010).

In the present study we showed that early age $(<25$ years $)$ of onset was found in $53.1 \%$ of patients with psoriatic arthritis. This was in contrast with Scarpa et al. (1984), they cleared that the peak age of onset of psoriatic arthritis in their psoriasis patients was 40-60 years. Also, $40.6 \%$ of the patients with psoriatic arthritis their disease had 25-45 years age of onset. Moreover, the disease had late age $(<45$ years) of onset in $6.3 \%$ of the patients with psoriatic arthritis. These results were expected as late age of onset is associated with less severe disease. Also, family history of psoriatic arthritis was insignificant risk factor $(\mathrm{OR}=4.47$, 95\% ECL: 0.22-267.35). Hellgren (1969) showed that familial clustering of psoriatic arthritis has been observed. But, there is no evidence that psoriatic arthritis follows Mendelian patterns of inheritance (Griffiths et al., 2010). Lastly, 56.2\% and $11.8 \%$ of the patients with- and without psoriatic arthritis, respectively had severe psoriasis (OR=9.64, 95\% CI: 3.15-30.55). Leonard et al. (1978) noticed an association between psoriatic arthritis and 
severe psoriasis, psoriatic arthritis is common in patients with severe psoriasis.

In this research we observed that $59.4 \%$ and $33.8 \%$ of the patients with- and without psoriatic arthritis were single, respectively. This result is concurring with Yosipovitch \& Tang (2002) and Zachariae et al. (2002a); they showed that patients living alone were more affected than married patients. Further, $78.1 \%$ and $97.1 \%$ of the patients with- and without psoriatic arthritis, respectively had history of recurrent pharyngitis. Moll and Wright (1973b) cleared that shared environment might plays an important role in the disease pathogenesis, as studies indicate that the disease is aggregates in certain families. Also, Vasey et al. (1982) noticed that positive immunoreactivity in the sera of these patients was increased, although establishing a pathogenic link has proved elusive and appears more tenuous than for psoriasis (Griffiths et al., 2010). Further, $90.6 \%$ and $39.7 \%$ of the patients with- and without psoriatic arthritis, respectively had stress/worry. Intriguingly, there is no significant relation between both the physical severity and psychological disability (Kirby et al., 2000\&2001). Lastly, $9.4 \%$ and $0.0 \%$ of the patients with- and without psoriatic arthritis, respectively had arthritis at site of trauma. This result concurring with Punzi et al. (1998) and Griffiths et al. (2010), as they cleared that trauma may be more important in psoriatic than in rheumatoid and other inflammatory forms of arthritis.

\section{CONCLUSIONS RECOMMENDATIONS}

AND

Psoriasis is a common skin disease. The epidemiology of disease is not well defined in Egypt. The heredity and environment, the most important risk factors, interact to play an essential role in psoriasis pathogenesis. Also, psoriatic arthritis is an important associated disease. The fact that it has no cure has important implications for how it should be viewed, prevented and treated. So, it could be recommended that more research should be carried out to understand the true epidemiological features of the disease in Egypt and its impacts on quality of life of the patients. 
Table (1): Distribution of clinical characteristics of the studied group of adult patients with psoriasis.

\begin{tabular}{|c|c|c|}
\hline Clinical characteristics & $\begin{array}{c}\text { Patients } \\
(n=100)\end{array}$ & Percent \\
\hline \multicolumn{3}{|l|}{ Age of onset (year): } \\
\hline Early: $20-<25$ & 37 & 37.0 \\
\hline $25-45$ & 44 & 44.0 \\
\hline Late: >45-64 & 19 & 19.0 \\
\hline Average age of onset: 31 years & -- & --- \\
\hline \multicolumn{3}{|l|}{ Gender: } \\
\hline Male & 48 & 48.0 \\
\hline Female & 52 & 52.0 \\
\hline \multicolumn{3}{|l|}{ Duration of psoriasis (year): } \\
\hline$<15$ & 68 & 68.0 \\
\hline$\geq 15$ & 32 & 32.0 \\
\hline \multicolumn{3}{|l|}{ Course: } \\
\hline Regression & 16 & 16.0 \\
\hline Stationary & 72 & 72.0 \\
\hline Progressive & 12 & 12.0 \\
\hline \multicolumn{3}{|l|}{ Severity: } \\
\hline Mild & 36 & 36.0 \\
\hline Moderate & 38 & 38.0 \\
\hline Severe & 26 & 26.0 \\
\hline \multicolumn{3}{|l|}{ Psychological disturbances: } \\
\hline Yes: & 56 & 56.0 \\
\hline Pathological worry & 27 & 27.0 \\
\hline Anxiety & 17 & 17.0 \\
\hline Depression & 12 & 12.0 \\
\hline \multicolumn{3}{|l|}{ Associated psoriatic arthritis: } \\
\hline \multicolumn{3}{|l|}{ Seasonal variation: } \\
\hline More in winter & 71 & 71.0 \\
\hline More in summer & 29 & 29.0 \\
\hline \multicolumn{3}{|l|}{ Suspected etiological risk factors: } \\
\hline Yes: & 82 & 82.0 \\
\hline Stress & 67 & 81.7 \\
\hline 3-month post-partum period ( 32 female patients) & 15 & 46.9 \\
\hline Pregnancy (32 female patients) & 3 & 9.4 \\
\hline Trauma & 14 & 17.1 \\
\hline Sunlight & 2 & 2.4 \\
\hline Medication & 2 & 2.4 \\
\hline \multicolumn{3}{|l|}{ Suspected protective factors: } \\
\hline Pregnancy (32 female patients) & 14 & 43.8 \\
\hline 3-month post-partum period ( 32 female patients) & 4 & 12.5 \\
\hline
\end{tabular}


Table (2): Distribution of psoriasis patients and control group according to their sociodemographic risk factors.

\begin{tabular}{|c|c|c|c|c|c|}
\hline \multirow[t]{2}{*}{ Sociodemographic factors } & \multicolumn{2}{|c|}{$\begin{array}{c}\text { Psoriasis } \\
\text { patients }(n=100)\end{array}$} & \multicolumn{2}{|c|}{$\begin{array}{c}\text { Control } \\
\text { group }(n=100)\end{array}$} & \multirow[t]{2}{*}{ OR・ $(95 \%$ CI••) } \\
\hline & No. & $\%$ & No. & $\%$ & \\
\hline $\begin{array}{l}\text { Marital status: } \\
\text { - Single } \\
\text { - Married } \\
\text { - Divorced and widowed }\end{array}$ & $\begin{array}{l}42 \\
27 \\
21\end{array}$ & $\begin{array}{l}42.0 \\
27.0 \\
21.0\end{array}$ & $\begin{array}{l}23 \\
63 \\
14 \\
\end{array}$ & $\begin{array}{l}23.0 \\
63.0 \\
14.0\end{array}$ & $\begin{array}{l}2.93(1.50-5.74) \\
0.22(0.11-0.41) \\
1.63(0.73-3.66)\end{array}$ \\
\hline $\begin{array}{l}\text { Educational level: } \\
\text { - Illiterate and read \& write } \\
\text { - Elementary } \\
\text { - Secondary and university }\end{array}$ & $\begin{array}{l}43 \\
34 \\
23\end{array}$ & $\begin{array}{l}43.0 \\
34.0 \\
23.0\end{array}$ & $\begin{array}{l}57 \\
33 \\
10\end{array}$ & $\begin{array}{l}18.9 \\
48.9 \\
32.2\end{array}$ & $\begin{array}{l}0.57(0.31-1.03) \\
1.05(0.56-7.96) \\
2.69(1.13-6.49)\end{array}$ \\
\hline $\begin{array}{l}\text { Occupation: } \\
\text { - Unskilled } \\
\text { - Semi-skilled and skilled } \\
\text { - Professional } \\
\end{array}$ & $\begin{array}{l}47 \\
41 \\
12 \\
\end{array}$ & $\begin{array}{l}47.0 \\
41.0 \\
12.0\end{array}$ & $\begin{array}{c}61 \\
30 \\
9 \\
\end{array}$ & $\begin{array}{l}25.6 \\
51.1 \\
23.3\end{array}$ & $\begin{array}{l}0.57(0.31-1.03) \\
1.62(0.87-3.04) \\
1.38(0.51-3.77) \\
\end{array}$ \\
\hline $\begin{array}{l}\text { Social class: } \\
\text { - Low } \\
\text { - Middle } \\
\text { - High }\end{array}$ & $\begin{array}{l}45 \\
38 \\
17\end{array}$ & $\begin{array}{l}45.0 \\
38.0 \\
17.0\end{array}$ & $\begin{array}{c}59 \\
32 \\
9\end{array}$ & $\begin{array}{c}59.0 \\
32.0 \\
9.0\end{array}$ & $\begin{array}{l}0.57(0.31-1.03) \\
1.30(0.70-2.43) \\
2.07(0.82-5.35)\end{array}$ \\
\hline
\end{tabular}

Table (3): Distribution of psoriasis patients and controls according to presence of some etiological risk factors.

\begin{tabular}{|c|c|c|c|c|c|}
\hline \multirow{2}{*}{$\begin{array}{l}\text { Etiological and } \\
\text { protective factors }\end{array}$} & \multicolumn{2}{|c|}{$\begin{array}{l}\text { Psoriasis patients } \\
\qquad(\mathrm{n}=\mathbf{1 0 0})\end{array}$} & \multicolumn{2}{|c|}{$\begin{array}{r}\text { Controls } \\
(\mathbf{n}=\mathbf{1 0 0})\end{array}$} & \multirow[t]{2}{*}{ OR・ $(95 \% \mathrm{CI} \bullet \bullet)$} \\
\hline & No. & $\%$ & No. & $\%$ & \\
\hline $\begin{array}{l}\text { Gender: } \\
\text { Male } \\
\text { Female }\end{array}$ & $\begin{array}{l}48 \\
52\end{array}$ & $\begin{array}{l}48.0 \\
52.0\end{array}$ & $\begin{array}{l}46 \\
54\end{array}$ & $\begin{array}{l}46.0 \\
54.0\end{array}$ & $\begin{array}{l}1.08(0.60-1.96) \bullet \bullet \\
0.92(0.51-1.67) \bullet \bullet\end{array}$ \\
\hline $\begin{array}{l}\text { History of recurrent pharyngitis: } \\
\text { Yes }\end{array}$ & 91 & 91.0 & 63 & 63.0 & $5.94(2.53-14.30)^{\bullet \bullet}$ \\
\hline $\begin{array}{l}\text { Smoking: } \\
\text { Yes: } \\
\quad<20 \text { cigarettes per day } \\
\geq 20 \text { cigarettes per day }\end{array}$ & $\begin{array}{l}64 \\
23 \\
41\end{array}$ & $\begin{array}{l}64.0 \\
23.0 \\
41.0\end{array}$ & $\begin{array}{l}52 \\
32 \\
20\end{array}$ & $\begin{array}{l}52.0 \\
32.0 \\
20.0\end{array}$ & $\begin{array}{l}1.64(0.90-3.01) \bullet \bullet \\
0.63(0.32-1.24) \bullet \bullet \\
2.78(1.41-5.50) \bullet \bullet\end{array}$ \\
\hline $\begin{array}{l}\text { Stress / worry: } \\
\text { Yes }\end{array}$ & 56 & 56.0 & 41 & 41.0 & $1.83(1.01-3.34) \bullet \bullet$ \\
\hline $\begin{array}{l}\text { Occupation exposing subject to } \\
\text { sunlight: } \\
\text { Yes }\end{array}$ & 21 & 21.0 & 13 & 13.0 & $1.78(0.79-4.05) \bullet \bullet$ \\
\hline $\begin{array}{l}\text { Medication: } \\
\text { Yes }\end{array}$ & 2 & 2.0 & 0 & 0.0 & Undefined \\
\hline $\begin{array}{l}\text { Psoriasis at site of trauma: } \\
\text { Yes }\end{array}$ & 14 & 14.0 & 0 & 0.0 & Undefined \\
\hline
\end{tabular}


Table (4): Distribution of psoriasis patients and controls according to family history (FH) risk factors.

\begin{tabular}{|c|c|c|c|c|c|}
\hline \multirow[t]{2}{*}{ Family history risk factors } & \multicolumn{2}{|c|}{$\begin{array}{c}\text { Patients } \\
(n=100)\end{array}$} & \multicolumn{2}{|c|}{$\begin{array}{c}\text { Controls } \\
(n=100)\end{array}$} & \multirow[t]{2}{*}{ OR・ $(95 \%$ ECL・•) } \\
\hline & No. & $\%$ & No. & $\%$ & \\
\hline Family history of psoriasis: & & & & & \\
\hline Yes: & 19 & 19.0 & 3 & 3.0 & $7.58(2.10-41.07)$ \\
\hline $1^{\text {st }}$ degree relatives & 13 & 13.0 & 2 & 2.0 & $7.32(1.58-68.08)$ \\
\hline $2^{\text {nd }}$ degree relatives or more & 6 & 6.0 & 0 & 0.0 & Undefined \\
\hline FH of $1^{\text {st }}$ degree relatives: & & & & & \\
\hline One parent: & 9 & 9.0 & 2 & 2.0 & $4.85(0.96-46.94)$ \\
\hline Father & 4 & 4.0 & 1 & 1.0 & $4.13(0.40-205.16)$ \\
\hline Mother & 5 & 5.0 & 1 & 1.0 & $5.21(0.56-248.88)$ \\
\hline Two parents & 3 & 3.0 & 0 & 0.0 & Undefined \\
\hline One sibling & 1 & 1.0 & 0 & 0.0 & Undefined \\
\hline
\end{tabular}

Table (5): Distribution of psoriasis patients' severity status by risk factors.

\begin{tabular}{|c|c|c|c|c|c|c|c|c|}
\hline \multirow{3}{*}{ Risk factors } & \multicolumn{6}{|c|}{ Psoriasis severity $(\mathrm{n}=100)$} & \multirow{3}{*}{$\chi^{2}$} & \multirow{3}{*}{$\begin{array}{c}\text { P- } \\
\text { Value }\end{array}$} \\
\hline & \multicolumn{2}{|c|}{ Mild (n=36) } & \multicolumn{2}{|c|}{ Moderate $(n=38)$} & \multicolumn{2}{|c|}{ Severe $(n=26)$} & & \\
\hline & No. & $\%$ & No. & $\%$ & No. & $\%$ & & \\
\hline $\begin{array}{l}\text { Marital status: } \\
\text { Single }\end{array}$ & 9 & 25.0 & 15 & 39.5 & 18 & 69.2 & 12.28 & 0.0021 \\
\hline $\begin{array}{l}\text { Educational level: } \\
\text { Secondary\& university }\end{array}$ & 6 & 16.7 & 8 & 21.1 & 9 & 34.6 & 2.88 & 0.2372 \\
\hline $\begin{array}{l}\text { Age of onset (year): } \\
\text { Early: }<25 \\
25-45 \\
\text { Late: }>45\end{array}$ & $\begin{array}{l}10 \\
15 \\
11\end{array}$ & $\begin{array}{l}27.8 \\
41.7 \\
30.5 \\
\end{array}$ & $\begin{array}{c}13 \\
18 \\
7\end{array}$ & $\begin{array}{l}34.2 \\
47.4 \\
18.4\end{array}$ & $\begin{array}{c}14 \\
11 \\
1\end{array}$ & $\begin{array}{c}53.8 \\
42.3 \\
3.9\end{array}$ & $\begin{array}{l}4.61 \\
0.28 \\
7.01 \\
\end{array}$ & $\begin{array}{l}0.0999 \\
0.8672 \\
0.0300 \\
\end{array}$ \\
\hline $\begin{array}{l}\text { Smoking: } \\
\quad \geq 20 \text { cigarettes per day }\end{array}$ & 9 & 25.0 & 14 & 36.8 & 18 & 69.2 & 12.65 & 0.0017 \\
\hline $\begin{array}{l}\text { Stress/worry } \\
\text { Yes }\end{array}$ & 14 & 38.9 & 19 & 50.0 & 23 & 88.5 & 15.95 & 0.0003 \\
\hline $\begin{array}{l}\text { Recurrent pharyngitis: } \\
\text { Yes }\end{array}$ & 29 & 80.6 & 36 & 94.7 & 26 & 100.0 & 8.01 & 0.0181 \\
\hline $\begin{array}{l}\text { Psoriasis family history: } \\
\text { Yes }\end{array}$ & 4 & 11.1 & 6 & 15.8 & 9 & 34.6 & 5.83 & 0.0542 \\
\hline $\begin{array}{l}\text { Psoriatic arthritis: } \\
\text { Yes }\end{array}$ & 6 & 16.7 & 11 & 29.0 & 15 & 57.7 & 11.94 & 0.0025 \\
\hline
\end{tabular}


Table (6): Distribution of clinical characteristics of the studied group of adult patients with psoriatic arthritis.

\begin{tabular}{|c|c|c|}
\hline Clinical characteristics & $\begin{array}{c}\text { Patients } \\
(\mathrm{n}=32)\end{array}$ & Percent \\
\hline \multicolumn{3}{|l|}{ Onset of psoriatic arthritis: } \\
\hline After psoriasis & 21 & 65.6 \\
\hline Before psoriasis & 6 & 18.8 \\
\hline With psoriasis & 5 & 15.6 \\
\hline Average age of onset: 43 years & -- & --- \\
\hline \multicolumn{3}{|l|}{ Gender: } \\
\hline Male & 15 & 46.9 \\
\hline Female & 17 & 53.1 \\
\hline \multicolumn{3}{|l|}{ Duration of psoriatic arthritis (year): } \\
\hline$<10$ & 18 & 56.2 \\
\hline$\geq 10$ & 14 & 43.8 \\
\hline \multicolumn{3}{|l|}{ Course: } \\
\hline Regression & 2 & 6.3 \\
\hline Stationary & 27 & 84.3 \\
\hline Progressive & 3 & 9.4 \\
\hline \multicolumn{3}{|l|}{ Severity: } \\
\hline Mild & 22 & 68.7 \\
\hline Moderate & 8 & 25.0 \\
\hline Severe & 2 & 6.3 \\
\hline \multicolumn{3}{|l|}{ Seasonal variation: } \\
\hline More in winter & 23 & 71.9 \\
\hline More in summer & 9 & 28.1 \\
\hline $\begin{array}{l}\text { Suspected etiological risk factor: } \\
\text { Trauma }\end{array}$ & 3 & 9.4 \\
\hline
\end{tabular}

Table (7): Distribution of psoriatic arthritis patients and controls according to some etiological risk factors.

\begin{tabular}{|c|c|c|c|c|c|}
\hline \multirow{2}{*}{ Etiological risk factors } & \multicolumn{2}{|c|}{$\begin{array}{c}\text { Psoriatic } \\
\text { arthritis }(n=32)\end{array}$} & \multicolumn{2}{|c|}{$\begin{array}{c}\text { Controls } \\
(\mathbf{n}=\mathbf{1 0 0})\end{array}$} & \multirow{2}{*}{$\begin{array}{l}\text { OR・ }(95 \% \text { CI••) } \\
\text { OR }(95 \% \text { ECL・••) }\end{array}$} \\
\hline & No. & $\%$ & No. & $\%$ & \\
\hline $\begin{array}{l}\text { Gender: } \\
\text { Male } \\
\text { Female }\end{array}$ & $\begin{array}{l}15 \\
17\end{array}$ & $\begin{array}{l}46.9 \\
53.1\end{array}$ & $\begin{array}{l}46 \\
54\end{array}$ & $\begin{array}{l}46.0 \\
54.0\end{array}$ & $\begin{array}{l}1.04(0.43-2.47) \bullet \bullet \\
0.97(0.40-2.31) \bullet \bullet\end{array}$ \\
\hline $\begin{array}{l}\text { History of recurrent pharyngitis: } \\
\text { Yes }\end{array}$ & 25 & 87.1 & 63 & 63.0 & $2.10(0.77-5.94) \bullet \bullet$ \\
\hline $\begin{array}{l}\text { Psoriatic arthritis family history: } \\
\text { Yes }\end{array}$ & 2 & 6.3 & 1 & 1.0 & $6.60(0.33-393.18) \bullet \bullet$ \\
\hline $\begin{array}{l}\text { Smoking: } \\
\text { Yes: } \\
\quad<20 \text { cigarettes per day } \\
\geq 20 \text { cigarettes per day }\end{array}$ & $\begin{array}{c}27 \\
8 \\
19\end{array}$ & $\begin{array}{l}84.4 \\
25.0 \\
59.4\end{array}$ & $\begin{array}{l}52 \\
32 \\
20\end{array}$ & $\begin{array}{l}52.0 \\
32.0 \\
20.0\end{array}$ & $\begin{array}{c}4.98(1.69-17.73) \bullet \bullet \bullet \\
0.71(0.26-1.89) \bullet \bullet \\
5.85(2.29-15.16) \bullet \bullet\end{array}$ \\
\hline $\begin{array}{l}\text { Arthritis at site of trauma: } \\
\text { Yes }\end{array}$ & 3 & 9.4 & 1 & 1.0 & $10.24(0.77-42.86) \bullet \bullet$ \\
\hline
\end{tabular}


Table (8): Distribution of psoriasis patients according to presence of psoriatic arthritis by some clinical risk factors.

\begin{tabular}{|c|c|c|c|c|c|}
\hline \multirow{3}{*}{ Clinical risk factors } & \multicolumn{4}{|c|}{ Psoriasis patients $(n=100)$} & \multirow{3}{*}{ 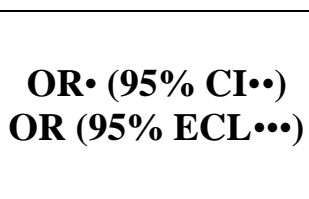 } \\
\hline & \multicolumn{2}{|c|}{$\begin{array}{l}\text { With arthritis } \\
\quad(n=32)\end{array}$} & \multicolumn{2}{|c|}{$\begin{array}{c}\text { Without } \\
\text { arthritis }(n=68)\end{array}$} & \\
\hline & No. & $\%$ & No. & $\%$ & \\
\hline Psoriasis age of onset (year): & & & & & \\
\hline Early: $<25$ & 17 & 53.1 & 20 & 29.4 & $2.72(1.05-7.12)$ \\
\hline $25-45$ & 13 & 40.6 & 31 & 45.6 & $0.82(0.32-2.08)$ \\
\hline Late: $>45$ & 2 & 6.3 & 17 & 25.0 & $0.33(0.03-1.52) \bullet \bullet \bullet$ \\
\hline Smoking: & & & & & \\
\hline$\geq 20$ cigarettes per day & 19 & 59.4 & 22 & 32.4 & $3.06(1.18-8.02)$ \\
\hline $\begin{array}{l}\text { Family history of psoriatic arthritis: } \\
\text { Yes }\end{array}$ & 2 & 6.3 & 1 & 1.5 & $4.47(0.22-267.35)^{\bullet}$ \\
\hline Psoriasis severity: & & & & & \\
\hline Mild & 6 & 18.8 & 30 & 44.1 & $0.29(0.09-0.86)$ \\
\hline Moderate & 8 & 25.0 & 30 & 44.1 & $0.42(0.15-1.17)$ \\
\hline Severe & 18 & 56.2 & 8 & 11.8 & $9.64(3.15-30.55)$ \\
\hline
\end{tabular}

Table (9): Distribution of psoriasis patients according to presence of psoriatic arthritis by some clinic-demographic characteristics.

\begin{tabular}{|c|c|c|c|c|c|c|}
\hline \multirow{3}{*}{$\begin{array}{l}\text { Clinic-demographic } \\
\text { characteristics }\end{array}$} & \multicolumn{4}{|c|}{ Psoriasis patients $(n=100)$} & \multirow{3}{*}{$\begin{array}{c}\chi^{2} \\
\mathbf{F E} \cdot\end{array}$} & \multirow{3}{*}{$\begin{array}{c}\text { P- } \\
\text { Value }\end{array}$} \\
\hline & \multicolumn{2}{|c|}{$\begin{array}{c}\text { With arthritis } \\
(\mathbf{n}=32)\end{array}$} & \multicolumn{2}{|c|}{$\begin{array}{c}\text { Without } \\
\text { arthritis }(n=68)\end{array}$} & & \\
\hline & No. & $\%$ & No. & $\%$ & & \\
\hline $\begin{array}{l}\text { Marital status: } \\
\text { Single }\end{array}$ & 19 & 59.4 & 23 & 33.8 & 4.83 & 0.0279 \\
\hline $\begin{array}{l}\text { Educational level: } \\
\text { Secondary/university } \\
\end{array}$ & 6 & 18.8 & 17 & 25.0 & 0.19 & 0.6613 \\
\hline $\begin{array}{l}\text { History of recurrent pharyngitis: } \\
\text { Yes }\end{array}$ & 25 & 78.1 & 66 & 97.1 & FE & 0.0044 \\
\hline $\begin{array}{l}\text { Stress / worry: } \\
\text { Yes }\end{array}$ & 29 & 90.6 & 27 & 39.7 & 20.88 & 0.0000 \\
\hline $\begin{array}{l}\text { Psoriatic arthritis at site of trauma: } \\
\text { Yes }\end{array}$ & 3 & 9.4 & 0 & 0.0 & $\mathrm{FE}$ & 0.0306 \\
\hline
\end{tabular}

- Fisher exact

\section{REFERENCES}

Andressen $C$ and Henseler $T$ (1982): Inheritance of psoriasis: Analysis of 2035 family histories. Hautarzt, 33:214-7.

Barker JNWN (2007): Genetics aspect of psoriasis. Clin Exp Dermatol, 26: 321-5.

Bell LM, Sedlack R and Beard CM (1991): Incidence of psoriasis in Rochester, Minnesota, 1980-83. Arch Dermatol, 127: 1184-7.

Bhalerao J and Bowcock AM (1998): The genetics of psoriasis: A complex disorder of the skin and immune system. Hum Mol Genetics, 7 (10): 1537-45.
Biodi-Oriente C, Scarpa R, Pucino A and Oriente $P$ (1989): Psoriasis and psoriatic arthritis: Dermatological and rheumatological co-operative report. Acta Derm Venereol, 146: 69-71.

Bos JD and DeCorte J (2008): Effects of etanercept on quality of life, fatigue and depression in psoriasis. Lancet, 367 (9504): 29-35.

Boyd AS, Morris LF, Phillips CM and Menter MA (1996): Psoriasis and pregnancy:Hormone and immune system interaction. Int J Dermatol, 35: 169-72. 
Brandrup F, Holm $\mathbf{N}$ and Grunnet $\mathbf{N}$ (1982): Genetics of psoriasis: Paternal inheritance and a locus on chromosome 6p. J Invest Dermatol, 62: 229-34.

Choi J and Koo J (2008): Quality of life issues in psoriasis. J Am Acad Dermatol, 49: S57-S61.

Devrimci-Ozguven H, Kundakci TN, Kumbasar $H$ and Boyvat A (2000): The depression, anxiety, life satisfaction and affective expression levels in psoriasis patients. J Eur Dermatol Venereol, 14: 267-71.

Duffy DL, Spelman LS and Martin NG (1993): Psoriasis in Australian twins. J Am Acad Dermatol, 29: 428-34.

Dunna SF and Finlay AY (1989): Psoriasis: improvement during and worsening after pregnancy. Br J Dermatol, 120: 584-8.

Elder JT, Henseler $\mathbf{T}$ and Christovers $\mathbf{E}$ (1994): Of genes and antigens: The inheritance of psoriasis. J Invest Dermatol, 103: 150S-3S.

Eyre RW and Krueger GG (1984): The Koebner response in psoriasis. In: Psoriasis, Roenigk HH and Maibach HI (Eds), New York, Marcel Dekker.

Farber EM and Nall ML (1974): The natural history of psoriasis in 5600 patients. Dematologica, 148: 1-18.

Farber EM and Nall ML (1985): Epidemiology: Natural history and genetics. In: Psoriasis, Roenigk $\mathrm{HH}$ and Maibach $\mathrm{HI}$ (Eds), New York, Marcel Dekker.

Feldman SR, Fleisher AB, Reboussin DM, Rapp SR, Exum ML and Clark AR (1996): The self-administered psoriasis area and severity index is valid and reliable. J Invest Dermatol, 106: 183-6.

Ferrandiz C, Pujol RM, Garcia-Patos V, Bordas $X$ and Smandia JA (2002): Psoriasis of early and late onset: A clinical and epidemiologic study from Spain. J Am Acad Dermatol, 46: 867-73.

Finlay AY and Kelly SE (1987): Psoriasis: Index of disability. Clin Exp Dermatol, 12: 811.

Fortune DG, Main CJ, O'Sullivan TM and Griffiths CE (1997): Assessing illness related stress in psoriasis: the psychometric properties of the Psoriasis Life Stress Inventory. J Psychosom Res, 42: 467-75.
Fortune DG, Richards HL, Kirby B and Griffiths CE (2002): A cognitive-behavioural symptoms programme as an adjunct in psoriasis therapy. Br J Dermatol, 46: 458-65.

Fortune DG, Richards HL, Kirby $B$ and Griffiths CE (2003): Psychological distress impairs clearance of psoriasis in patients treated with photo-chemotherapy. Arch Dermatol, 139: 752-6.

Fortune DG, Richards HL, Main CJ and Griffiths CE (1998): What parients with psoriasis believe about their condition. J Am Acad Dermatol, 39: 196-201.

Gelfand JM, Feldman SR, Stern RS, John Thomas MS, Rolstad T and Margolis DJ (2004): Determinants of quality of life in patients with psoriasis: A study from US population. J Am Acad Dermatol, 51: 704-8.

Gladman DD (2002): Current concepts in psoriatic arthritis. Curr Opin Rheumatol, 14 (4): 361-6.

Gladman DD, Shuckett $R$ and Russell ML (1987): Psoriatic arthritis (PSA): An analysis of 220 cases. Q J Med, 62: 127-41.

Griffiths CEM, Camp RDR and Barker JNWN (2010): Psoriasis. In: Rook's textbook of dermatology, $8^{\text {th }}$ ed., Burns T, Breathnach $\mathrm{S}$, Cox N and Griffiths C (Eds), Blackwell Science; Oxford, London, Vol. 4.

Grob JJ and Folchetti G (1999): Epidemiology of psoriasis. In: Text book of psoriasis, Van de Kerkhof P (Ed). London, Blackwell Science.

Gudjonsson JE, Karason A and Antonsdottir AA (2002): HLA-Cw6- positive and HLA-Cw6-negative patients with psoriasis vulgaris. J Am Acad Dermatol, 118: 450-6.

Gupta MA, Gupta AK and Kirkby S (1989): A psycho-cutaneous profile of psoriasis who are stress reactors: A study of 127 patients. Gen Hosp Psychatry, 11: 166-73.

Gupta MA, Gupta AK and Watteel GN (1998): Perceived deprivation of social touch in psoriasis is associated with greater psychologic morbidity: An index of the stigma experience in dermatologic disorders. Cutis, 61: 339-42.

Hellgren L (1967): Psoriasis: The prevalence in sex, age and occupational groups in total population in Sweden. Morphology, 
inheritance and association with other skin and rheumatic diseases. Stockholm: Almqvist \& Wiksell.

Hellgren L (1969): Association between rheumatoid arthritis and psoriasis in total populations. Acta Rheumatol Scand, 15: 31626.

Henseler T and Christophers E (1985): Psoriasis of early and late onset: Charactrization of two types of psoriasis vulgaris. J Am Acad Dermatol, 13: 450-6.

Higgins E (2000): Alcohol, smoking and psoriasis. Clin Exp Dermatol, 25: 107-10.

House A and Stark D (2002): ABC of psychological medicine: Anxiety in medical patients. BMJ, 325: 207-9.

Javitz HS, Ward MM, Farber E, Nail $L$ and Vallow SG (2002): The direct cost of care for psoriasis and psoriatic arthritis in the US. J Am Acad Dermatol, 46: 850-60.

Kirby B, Fortune DG, Bhushan M, Chalmers RJ and Griffiths CE (2000): The Salford Psoriasis Index: A holistic measure of psoriasis severity. Br J Dermatol, 142: 728-32.

Kirby B, Richards HL, Woo P, Hindle E, Main CJ and Griffiths CE (2001): Physical and psychologic measures are necessary to assess overall psoriasis severity. J Am Acad Dermatol, 45: 72-6.

Koo J (1996): Population-based epidemiological study of psoriasis with emphasis on quality of life assessment. Dermatol Clin, 14: 485-96.

Krueger G, Koo J, Lebwohl M, Menter A, Stern RS and Rolstad T (2001): The impact of psoriasis on quality of life: Results of a 1998 National Psoriasis Foundation PatientMembership Survey. Arch Dermatol, 137: 280-4.

Langley RG, Krueger GG and Griffiths (2005): Psoriasis: Epidemiology, clinical features and quality of life. Ann Rheum Dis, 64 (Suppl 2): ii18-23.

Leonard DG, O'Duffy JD and Rogers RS (1978): Prospective analysis of psoriatic arthritis in patients hospitalized for psoriasis. Mayo Clin Proc, 53: 511-8.

Lebwohl M and Ali S (2001a): Treatment of psoriasis. Part 1: Topical therapy and phototherapy. J Am Acad Dermatol, 45:48798, quiz 499-502.

Lebwohl M and Ali S (2001b): Treatment of psoriasis. Part 2: Systemic therapy. J Am Acad Dermatol, 649-61, quiz 662-4.

McKenna S, Lebwohl $M$ and Kahler K (2005): Development of the US PSORIQoL: A psoriasis-specific measure of quality of life. Int J Dermatol, 44: 462-9.

Mease $P$ and Goffe BS (2005): Diagnosis and treatment of psoriatic arthritis. J Am Acad Dermatol, 52: 1-15.

Moll JMH and Wright V (1973a): Psoriatic arthritis. Semin Arthritis Rheum, 3: 55-78.

Moll JMH and Wright V (1973b): Familial occurrence of psoriatic arthritis. Ann Rheum Dis, 22: 181-201.

Naldi L, Peli L and Parazzini F (1999): Association of early-stage psoriasis with smoking and male alcohol consumption: Evidence from Italian case- control study. Arch Dermatol, 135: 1479-84.

Nevitt G and Hutchinson P (1996): Psoriasis in the community: Prevalence, severity and patient's beliefs and attitudes towards the disease. Br J Dermatol, 135: 533-7.

Petros E and Joseph M (2006): Psoriatic Arthritis. In: Manual of rheumatology and outpatient orthopedic disorders: Diagnosis and therapy $5^{\text {th }}$ ed., Stephen A Paget et al. (EDs), Lippincott Williams \& Wilkins.

Punzi L, Pianon M and Bertazzolo N (1998): Clinical, laboratory and immunogenetic aspects of post-traumatic psoriatic arthritis: A study of 25 patients. Clin Exp Rheumatol, 16: 277-81.

Rapp SR and Feldman SR (2004): The promise and challenge of new biological treatments for psoriasis: How do they impact quality of life? Dermatol Ther, 17: 376-82.

Reveille JD, Conant MA and Duvic M (1990): Human immunodeficiency virus psoriasis, psoriatic arrhritis and Reiter's syndrome; a disease continuum. Arthritis Rheum, 33: 1574-8.

Richards HL, Fortune DG, Griffiths CE and Maine CJ (2001): The contribution of perceptions of stigmatisation to disability in patients with psoriasis. J Psychosom Res, 50: $11-5$. 
Roberts MET, Wright $\mathrm{V}$ and Hill AGS (1976): Psoriatic arthritis: Follow up study. Ann Rheum Dis, 35: 206-12.

Ros A-M and Eklund G (1987): Photosensitive psoriasis. J Am Acad Dermatol, 17: 7521-8.

Sander HM, Morris LF and Phillips CM (1993): The annual cost of psoriasis. J Am Acad Dermatol, 28: 422-5.

Savin JA (1970): Patients' beliefs about psoriasis. Trans St Johns Hosp Dermatol Soc, 56: 139-42.

Scarpa R, Oriente P, Pucino A and BiodiOriente C (1984): Psoriatic arthritis in psoriatic patients. Br J Rheumatol, 23: 246-50.

Smith AE, Kassab JY, Rowland Payne CME and Beer WE (1993): Bimodality in age of onset of psoriasis in both patients and their relatives. Dermatology, 186: 181-6.

Stein KR, Pearce DJ and Feldman SR (2005): The impact of biologics on the quality of life of psoriasis patients and the economics of psoriasis care. Semin Cutan Med Surg, 24 (1): 52-7.

Stern RS (2003): Assessing the safety of immuonologic modifier for the treatment of chronic disease: The psoriasis paradigm. $\mathbf{J}$ Invest Dermatol, 120: xi-xii.

Stern RS, Nijsten T, Feldman SR, Margolis DJ and Rolstad $T$ (2004): Psoriasis is common, carries a substantial burden when extensive and is associated with wide spread treatment dissatisfaction. J Invest Dermatol Proc, 9: 136-9.

Stuart P, Malick F and Nair RP (2002): Analysis of phynotypic variation in psoriasis as a function of age at onset and family history. Arch Dermatol Res, 294: 207-13.

Telfer NR, Chalmers RJ, Whale $K$ and Kolman G (1992): The role of streptococcal infection in the initiation of guttat psoriasis. Arch Dermatol, 128: 39-42.
Tervaert WC and Esseveld H (1970): A study of the incidence of haemolytic streptococci in the throat in patients with psoriasis vulgaris, with reference to their role in the pathogenesis of this disease. Dematologica, 140: 282-90.

Vasey FB, Deitz C, Fenske NA, Germain BF and Espinosa LR (1982): Possible involvement of group A streptococci in the pathogenesis of psoriatic arthritis. J Rheumatol, 9: 719-22.

Weiss SC, Kimball AB, Liewehr DJ, Blauvelt A, Turner ML and Emanuel EJ (2002): Quantifying the harmful effect of psoriasis on health-related-quality of life. J Am Acad Dermatol, 47(4): 521-8.

Yosipovitch G and Tang MB (2002): Practical management of psoriasis in the elderly: Epidemiology, clinical aspects, quality of life, patient education and treatment otions. Drugs Aging, 19(11): 847-63.

Yui Yip S (1984): The prevalence of psoriasis in the mongoloid race. J Am Acad Dematol, 10: $965-8$.

Zachariae H, Zachariae R, Blomqvist K, Davidson S, Molin $\mathrm{L}$, Mork $\mathrm{C}$ and Sigurgeirsson B (2002a): Quality of life and prevalence of arthritis reported by 5,759 members of the Nordic Psoriasis Association: Data from the Nordic Quality of Life Study. Acta Derm Venereol, 82 (2): 108-13.

Zachariae R, Zachariae H, Blomqvist $\mathrm{K}$, Davidson S, Molin $\mathrm{L}$, Mork $\mathrm{C}$ and Sigurgeirsson B (2002b): Quality of life in 6,479 Nordic patients with psoriasis. Br J Dermatol, 146: 1006-16. 


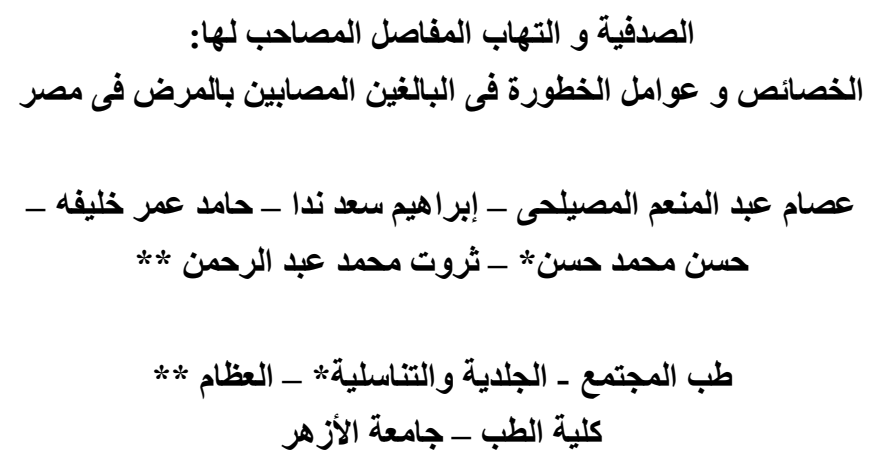

أجريت هذه الدراسـة على 100 مريض بـالغ مصـاب بالصدفية من المترددين على عيادة الأمر اض الجلديـة

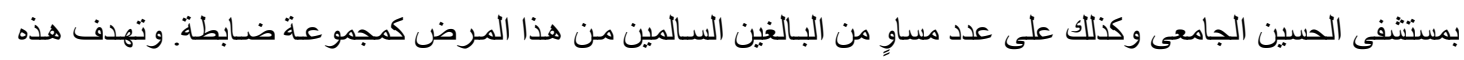

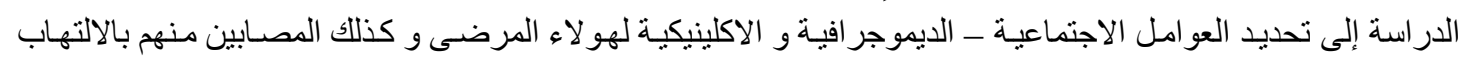

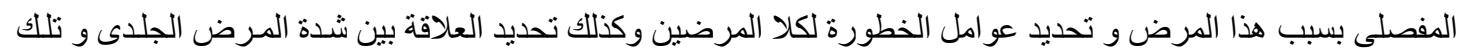

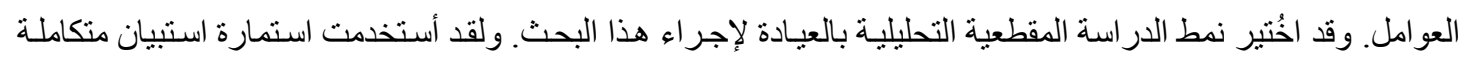

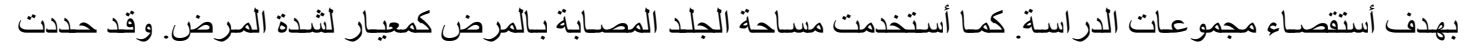

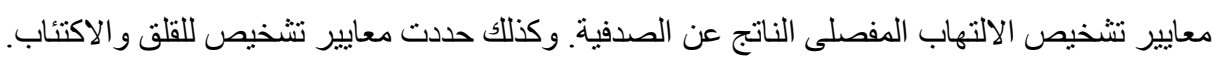

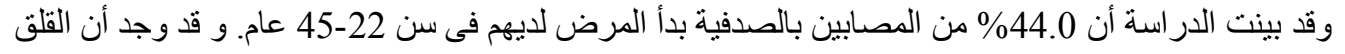

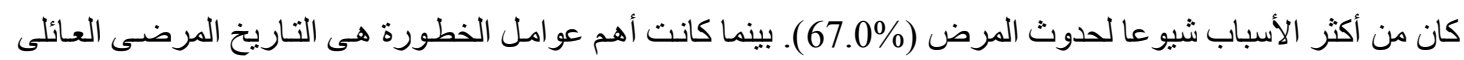

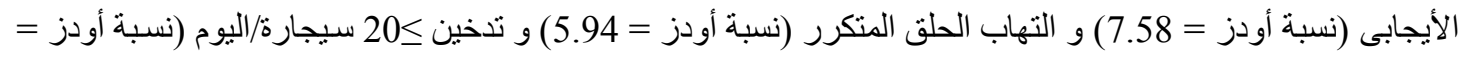

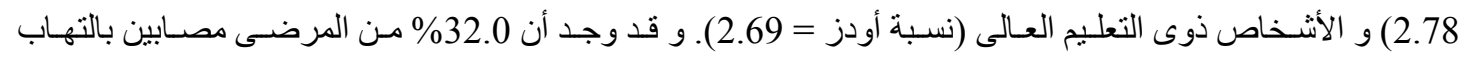

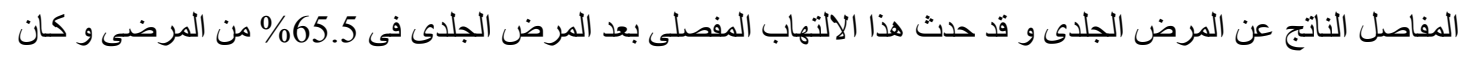

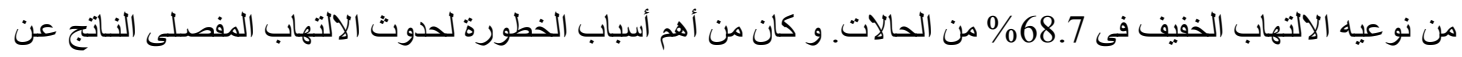

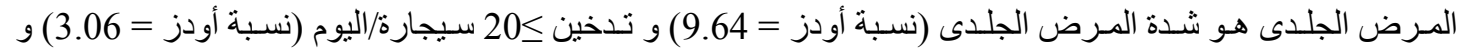

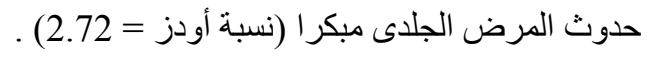

